\title{
Operational Excellence as the Main Customer Value: Information Technology Vendors' Perspective
}

\author{
Christof Gellweiler \\ WHU - Otto Beisheim School of Management, Vallendar, Germany
}

\section{Abstract}

Background: Information technology (IT) requires substantial investments from enterprises to build competitive capabilities. IT products are supposed to provide value to customers and to increase the competitiveness of enterprises. Vendors of IT products should take the competitive strategy and value creation for enterprise buyers into account. Objectives: This article takes the perspective of IT vendors (ITVs) and attempts to answer the research questions "What types of customer value do ITVs consider?" and "Do ITVs consider the competitiveness of enterprises?" Methods/Approach: This research investigates descriptions from ITVs and analyzes patterns and correlations of coded content. The annual reports of 32 global marketleading ITVs were examined through direct content analysis. Results: Half of the annual reports mention the competitiveness of enterprise buyers; $84 \%$ of the samples relate to customer-value disciplines. Moderate positive and monotonic relationships were detected between customer value disciplines. Conclusions: ITVs consider the competitiveness of buyers and noticeably regard customer value disciplines, mainly operational excellence, that in turn refers to process efficiency and costeffectiveness.

Keywords: Competitiveness, customer value, IT vendors, IT strategy, operational excellence, business-IT alignment

JEL classification: M15, L86

Paper type: Research article

Received: Apr 4, 2018

Accepted: Sep 22, 2018

Citation: Gellweiler, C. (2019), "Operational Excellence as the Main Customer Value: Information Technology Vendors Perspective," Business Systems Research, Vol. 10 No. 1, pp. 13-30.

DOI: $10.2478 / \mathrm{bsrj}-2019-0002$

\section{Introduction}

In order to increase their competitiveness, enterprises must acquire resources and enhance capabilities that provide customer value and that are hard for other market players to attain (Barney, 1991). Information technology (IT) products are central resources in an enterprise's operation and consequently provide the basis for building capabilities for value delivery and for competitive advantage (Clemons and Row, 1991; Drnevich and Croson, 2013; McAfee and Brynjolfsson, 2008; Peppard and Ward, 2004, 2005; Venkatraman, Henderson, and Oldach, 1993). In general, 
operational IT products are significant capital investments that should provide backflows (ISACA, 2010). IT strategy is concerned with IT supply (Peppard and Ward, 2016). Thus, vendors of IT products play a pivotal role in both IT strategies (Ward, 2012) and value delivery (Chicksand and Rehme, 2018). Their products must meet the requirements specified by enterprises (IIBA, 2015), and they are a source of innovation for introducing new products in enterprises (Vishnevskiy, Karasev, and Meissner, 2016). Therefore, IT vendors (ITVS) must be clear on how their products can enhance the competitiveness of their business buyers, i.e., enterprises, and must be clear on what type of value can be provided to end customers.

To date, business-systems science has paid little attention to ITVs and their perspectives on the enterprise competitiveness and customer value that result from their products (Singh and Paliwal, 2012). Furthermore, the types of values that IT products deliver needed more clarification (Gandelman, Cappelli, and Santoro, 2017; Lieberman, Balasubramanian, and Garcia-Castro, 2018). The values generated for customers by information systems might be low prices, new features or functions, or a solution to a customer-specific problem. Customer values can be distinguished in three distinct types, namely, product leadership, operational excellence, and customer intimacy (Treacy and Wiersema, 1995). These types and their significant implications for competitiveness have been neglected in past IT-strategy studies.

This paper proposes to explore the connection between IT products and IT strategy in view of competitiveness and customer value. It aims to identify the types of customer value provided by IT products and to discover patterns among them. The goal is to understand better the impacts of IT products on competitiveness and the types of value that IT products generate. The phenomena may be studied from the buyer or from the supplier side. In this paper, the supplier side has been selected, specifically ITVs. Despite an increased interest in business-IT alignment, it is surprising that so little research has been conducted on IT products and their competitive consequences, especially from the perspective of ITVs. This study remedies these deficiencies by revealing the views of ITVs on the competitiveness of their buyers and on the types of value delivered to end customers, as indicated when ITVs describe their products and their business in annual reports.

As little is known about the theoretical foundation of customer value from IT products, qualitative research was employed in order to explore the context (Creswell, 2013). Qualitative research is assumed to be better suited to building theories (Myers, 2013), and so the chosen approach was inductive. Exploratory research starts from the bottom and begins with data collection, followed by analysis and development of propositions (Myers, 2013; Van de Ven, 2007). The documentcontent analysis was the selected qualitative method; it concerns context, meanings, and intentions. Inferences are made about written texts in systematic and objective ways to describe and quantify a phenomenon (Downe-Wamboldt, 1992). Latent content analysis (Hsieh and Shannon, 2005) was applied to documents from ITVs. Annual reports were chosen as the document type because they are addressed to investors and they provide more reliable and more trustworthy information than marketing documents. Business descriptions and product presentations within the annual reports of 32 global market-leading ITVs were studied using codes for competitiveness and customer value. Content categories and coding units for customer value were defined using concepts from Treacy and Wiersema (1995). The frequency of hits of coding units was evaluated, and correlations were calculated.

This study of ITVs' views on customer value is significant to business systems theory for several reasons. First, it demonstrates that the customer-value disciplines of Treacy and Wiersema (1995) are appropriate for typifying IT values. Second, it generates the 
proposition that operational excellence is the most prevalent customer-value type from IT products. Third, the study discerns patterns and correlations between competitiveness and customer-value disciplines. IT strategists in practice may purposefully align their investments in IT products to customer values as defined in their business strategy.

The paper has been organized as follows. The literature review integrates the strategic implications of IT products and illuminates the role of ITVs in affecting customer value and competitiveness. The methods of content analysis are then presented in detail, including selections of content, samples, and units of analysis. Additionally, the coding agenda, containing the categories and coding units, is provided. The results are reported by the number of hits of context units in the studied annual reports. The findings are described by percentage shares of customer values and correlations among the content categories. The discussion and conclusion sections present interpretations of the findings as answers to the research questions, address the limitations and assumptions of the study, and suggest directions for future research.

\section{Literature review}

\section{IT as an essential part of an enterprise's competitive strategy}

According to Clemons and Row (1991), IT is central to a firm's competitive strategy. Strategic planning of IT comprises finding computer applications that help to achieve the business goals of an organization (Lederer and Salmela, 1996). All primary and support activities within the generic value chain generate and use information (Porter, 1985). Consequently, IT is present in all parts of the value chain and is critical for linking information between the activities of a firm.

Technology influences competitive advantage if it affects costs or differentiation, and therefore it supports generic strategies such as cost leadership or focus (Porter, 1980, 1985). Technology strategy is the method of developing and applying technology to contribute to the overall strategy pursued by a company (Porter, 1985). For IT, this idea has unfolded in various approaches, such as architecture management (The Open Group, 2011), business analysis (IIBA, 2015), or the 'Enterprise Information Technology Body of Knowledge' (IEEE, 2017). The aim is to plan and implement IT that supports an enterprise's strategy for competitive advantage.

The need to fit IT with other elements of an enterprise's strategy is of growing interest in science and practice. For instance, the resource-based view, which is the dominant analytical, strategic tool for achieving sustainable competitive advantage, has been extended to analyze and plan IT capabilities (Wade and Hulland, 2004). Luftman (2003) suggested that the IT architecture and IT strategy should enhance the business and align to the enterprise strategy. Contemporary ITmanagement frameworks, e.g., TOGAF (The Open Group, 2011) or COBIT (ISACA, 2012), are becoming increasingly popular in industrial practice as ways to utilize technology for the support of competitive strategy in structured ways. There are many ongoing discussions on how best to develop IT in enterprises according to their business strategy. IT managers have stressed the importance of aligning IT with business strategy (El-Mekawy, Rusu, and Perjons, 2015; Luftman, 2003; Marrone and Kolbe, 2011). In 2013, researchers from IBM conducted interviews globally with 875 CEOs in various industries and found that most executives described a strong impact of technology on strategy (Berman and Marshall, 2014). IT is a crucial part of an 
enterprise's competitive strategy. IT capabilities must fit the enterprise's strategy and additionally provide value to customers.

\section{Customer value from capabilities produced by IT products}

Broadly speaking, the competitiveness of an enterprise is dependent on its ability to sell and deliver products (goods, services, results, or combinations) that are more highly valued by customers compared to those of its rivals in a specific market. Michael Porter has provided a meaningful definition of value (1985, p. 3): "Value is what buyers are willing to pay, and superior value stems from offering lower prices than competitors for equivalent benefits or providing unique benefits that more than offset a higher price." Value creation is the key to profitability and competitiveness (Dranove and Marciano, 2005). Although the notion of value creation has been discussed for several decades, its definition and the meaning of the concept are still unclear (Lieberman, Balasubramanian, and Garcia-Castro, 2018). Little research has been done on the concept of value, although IT value is one of the more investigated subjects. The research focus has been on evaluation methods for IT investments, and scholars have lacked an understanding of the concept of IT value (Gandelman, Cappelli, and Santoro, 2017).

Recognized studies regarded IT as an enterprise resource (Bharadwaj, 2000; Feeny and Willcocks, 1998; Wade and Hulland, 2004) or as an enterprise capability (Peppard and Ward, 2004) for value creation. Daulatkar and Sangle (2016) described the concept of IT business value and argued that IT supports companies in fulfilling their product objectives and their strategic vision for competing in innovative markets. Martins and Zacarias (2017) present products and values as elements of the service layer of "Business Process and Practice Alignment Methodology." Christensen (2010) connected the business value and competitiveness by saying that the type of value is of secondary importance; more relevant for competitive advantage is a customer or user's motivation for buying products from an enterprise rather than from its competitors.

Customer value from IT products requires more clarity and further exploration. Moreover, the relationship between customer value and an enterprise's competitiveness is of interest. Tallon (2007) analyzed IT business value under various strategies and used Treacy and Wiersema's (1995) value disciplines, which enterprises can use to create customer value. These value disciplines are three generic approaches to offering outstanding advantages to customers: product leadership, operational excellence, and customer intimacy. Companies compete on innovation, newness, superior design, and short time-to-market when pursuing product leadership, whereas operational excellence focuses on offering the lowest price by producing high volumes or providing high process efficiency. Enterprises may also compete by formulating and implementing customer intimacy as a value discipline, offering products tailored to individual needs and cultivating relationships with customers.

\section{ITVs are connected to customer value and IT strategy}

Chicksand and Rehme (2018) extended the definition of value to business relationships; total value integrates the perspectives of the buyer and suppliers that share the entire value. ISACA $(2012$, p. 17) demonstrates the increasing influence of external IT parties, such as service providers and suppliers, that contribute to delivering the expected value. Some external vendors play a critical role in supporting an enterprise's business (ISACA, 2012, p. 76). Suppliers provide specialist skills, goods, and services to create outcomes required by customers and users 
(Office of Government Commerce, 2002, p. 6). Moreover, suppliers build trustful relationships with their buyers (Duc, Siengthai, and Page, 2013). Feeny and Willcocks (1998) introduced nine information-systems core capabilities. In one of them, the "vendor development" capability, they identified the potential for long-term supplier/buyer relationships that extend revenues for both and allow them jointly to understand the business for common growth.

"The concept of IT-value planning" (Gellweiler, 2017, p. 145) reflects the dependency of IT products on enterprise strategy. It describes the link between competitive strategy and IT-product requirements. According to this idea, requirements for new IT products must support the competitive strategy of enterprises and must relate to value creation. Goods, services, and solutions from ITVs must meet the IT-product requirements that enterprises specify, e.g., new features and functions. Consequently, the requirements of enterprises need to be well understood by vendors and bidders (IEEE, 2017). The reliability of ITVs and the fulfillment of requirements may be formally assessed through responses to requests for information (RFI) or requests for proposal (RFP) from enterprises (IIBA, 2015). Products from ITVs are logically linked via these requirements to the competitiveness and value creation of enterprises. Figure 1 depicts an adapted sequence for IT-value planning and highlights ITVs, which must fulfill those requirements with their IT products.

Figure 1

IT products meet requirements derived from the competitive strategy

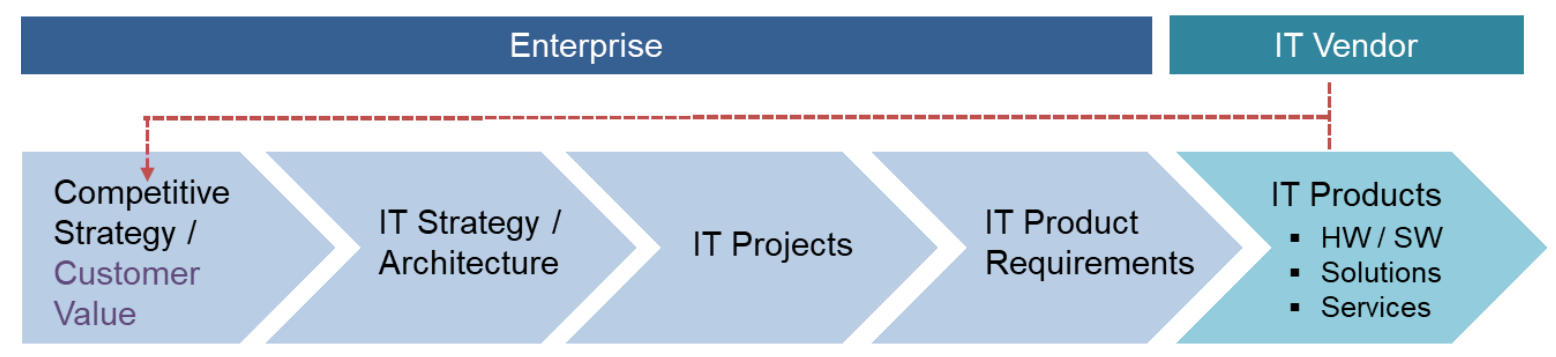

Source: Adapted from Gellweiler (2017)

In conclusion and according to Ward (2012), IT products and their suppliers exercise a critical influence on enterprises' strategic information systems. Singh and Paliwal (2012) have pointed out that value creation has been examined extensively in buyer/seller relationships, but research on customer value is still immature. They also stress the importance of creating value for end customers as part of the buyer's value chain.

\section{Research problem}

This research explored the connection between IT products and business strategy from a vendor perspective. It attempted to discover whether ITVs reflect enterprise competitiveness and customer-value creation when describing their IT products and their business in annual reports.

ITVs are suppliers of hardware, software, and services to enterprises. Those deliverables may be considered as resources and inputs to an enterprise. Enterprises combine them and further develop capabilities within their organizations. Superior capabilities from combined IT products provide value to the customers of an enterprise and increase enterprises' competitiveness. 
The research sought to answer two questions. The first, "What types of end customer value do ITVs consider?" asked for the typology of customer values from IT products and referred to the frequency of each type. The second, "Do ITVs consider the competitiveness of enterprises?" looked for the frequency of codes for competitiveness. Furthermore, patterns and correlations between competitiveness and value disciplines were examined. The contents of the annual reports of selected ITVs were evaluated on determined coding units to answer the research questions.

\section{Methodology}

\section{Philosophical assumptions}

Pragmatist philosophy underlies the selections of research strategy and methods of data collection and evaluation. Epistemology, ontology, and axiology are adopted as appropriate for answering the research questions (Saunders, Lewis, and Thornhill, 2016). Pragmatists focus on outcomes and solutions and have free choice on techniques that are suitable to the purpose (Creswell, 2013). The data collection and numerical analysis strove for objectivity and avoided conscious bias. In contrast, the discussion of findings and conclusion are interpretations and, hence, value-laden. They reflect the researcher's subjective views.

\section{Content analysis}

Content analysis was the chosen technique for gathering and analyzing textual content in documents. Textual data create categories and explanations in inductive ways (Pope, Ziebland, and Mays, 2000). "Inductive content analysis is used in cases where there are no previous studies dealing with the phenomenon" (Elo and Kyngäs, 2008, p. 107). Content analysis helps to answer research questions that have a wider exploratory purpose (Saunders, Lewis, and Thornhill, 2016). This methodology is based on coding and categorizing qualitative data for quantitative evaluation. Content analysis is a mature scientific method that adheres to principles of objectivity, systematic structure, and generalizability. One purpose is to pose the features of the content. Quantitative expressions can be made that provide specific and objective data about the phenomenon and yield meaningful results (Prasad, 2008), e.g., concepts or categories, that describe the phenomenon (Sandelowski, 1995).

The content analysis must be carried out in a transparent, replicable, and consistent manner (Saunders, Lewis, and Thornhill, 2016). In line with Prasad (2008), the following steps were carried out:

- Selection of content and samples.

- Development of content categories.

- Selection of units of analysis.

- Preparation of a coding agenda.

- Data collection and evaluation.

\section{Selection of content}

To answer the research question, annual reports were selected for two reasons as the type of document under investigation. First, annual reports contain tight and meaningful descriptions of a business and the products that are created for investors. These descriptions are therefore more reliable and trustworthy than other sources. Annual reports are prepared for analysts and reflect strategy and financial performance by means of balance sheets, cash-flow statements, and income statements. Infringements in annual reports may result in notable impacts for ITVs, particularly losses in share value. 
Second, annual reports provide better comparability between ITVs because of standardization and the similar lengths of texts for business and product descriptions. Also, annual reports are more self-reflective. Authors present the companies' views and not opinions from outside, such as those of industry or business analysts from external consulting firms or the press. Compared to advertising web pages, product sheets, or brochures that try to convince customers by using fashionable terminology, annual reports are not in suspicion because of the use of buzzwords or jargon. Thus, text coding is expected to be less distorted when analyzing annual reports. Another advantage of documents is their unaffectedness by the research process and their "unobtrusiveness" (Bowen, 2009).

Companies traded on stock exchanges in the United States are obliged to submit Form 10-K from the U.S. Securities and Exchange Commission (SEC). In addition to financial data, 10-K reports include the business section (Part I, Item 1), in which companies concisely describe their operation and their offers. For document analysis of companies that do not trade on stock exchanges in the USA, apposite sections of annual reports were selected.

The studied documents were the most recent annual reports published by the nominated ITVs at the time of sampling (November 2016). All reports were written in English so that a common linguistic platform would be available for coding.

\section{Selection of samples}

In qualitative research, the determination of a suitable sample strategy and size relies on the researcher's judgment and must be defended as reasonable for the purpose (Sandelowski, 1995, 2000). There is no recognized number of samples when applying content analysis. The sample size should be established as information is required to adequately answer the research question (Bengtsson, 2016), to draw conclusions from analytical findings (Brislin, 1979), or to provide results in a new and wellstructured understanding (Sandelowski, 1995). According to Sandelowski (1995), at least 25 samples may be required. Goh and Ryan (2008) sampled 16 companies for content analysis and noted this sample size as a limitation. Robertson and Samy (2015) regarded 22 samples for content analysis of annual reports as a constraint for representativeness.

According to Palinkas et al. (2015), purposeful sampling is a broadly applied method in qualitative research for identifying and selecting cases that provide rich information on the phenomenon under investigation. Thus, purposeful sampling allows researchers to select cases for best achievement of their research goals. The representativeness of data collection can be increased by heterogeneous sampling (Saunders, Lewis, and Thornhill, 2016). For this study, 32 samples were selected for the purpose. The choice of ITVs was based on product type and size in terms of revenues. Another criterion for selection was the targeted customer category. Some ITVs operate only in consumer markets, while other vendors act as suppliers to other ITVs. For the sample selection, ITVs had to target enterprises that buy and use IT for primary and support activities in their value chain. The target enterprises did not consider IT their sole core competency but needed IT for innovation and competitiveness. At least one business segment of the ITV had to serve organizations in competitive environments, regardless of the industry. Vendors' products were not to be specific to one industry. Excepted were ITVs that mainly supply other ITVs. In addition, providers for Internet or data transmission services (so-called carriers, telecom-service providers, Internet-service providers, and network operators) were left out. Such services are considered commodities with low potential for IT product differentiation. 
In order to increase the variability of geographical distribution, samples were chosen across the continents.

For the assortment of ITVs to be sampled, the Forbes Global 2000 list for 2014 was used. It was downloadable as a file in CSV format for post-processing in Microsoft Excel. From there, I extracted all firms allocated to the sector "Information Technology," which is one of 11 sectors in the Forbes Global 2000 list. The next level down in selection was "Industry" as a parameter in the same list. The industry types "Computer \& Electronic Retail," "Electronics," and "Semiconductors" were excluded from further analysis, while the industry types "Communications Equipment," "Computer Hardware," "Computer Services," "Computer Storage Devices," and "Software \& Programming" passed this filtering stage. The type "Computer \& Electronic Retail" was not investigated because target buyers include consumers. The types "Electronics" and "Semiconductors" were not examined, as these types of firms supply ITVs, i.e., they are parts of ITVs' value chains.

From the remaining industry types, I selected for each continent the four biggest vendors in terms of sales. The possible options for continents at this stage were North America, Europe, and Asia. Not every continent of those was represented by two vendors per industry type. Some ITVs had to be taken out of consideration because the business product and target groups were inappropriate, e.g., the target customers of Alcatel-Lucent and Ericsson are network operators or telecom/Internetservice providers. Other vendors were omitted because they solely supply to other ITVs (e.g., Western Digital's data-storage products) or provide IT commodities such as screens (TPV Technology). Out of 60 possible combinations (five industry types, three continents, four vendors per category and continent), 32 vendors were finally chosen for document research. Figure 2 depicts the scope of vendor/buyer relationships for answering the research questions. Excluded types of vendor/buyer relations are symbolized by grey arrows and boxes.

Figure 2

Relationships between IT vendors and buyers in the scope of the research

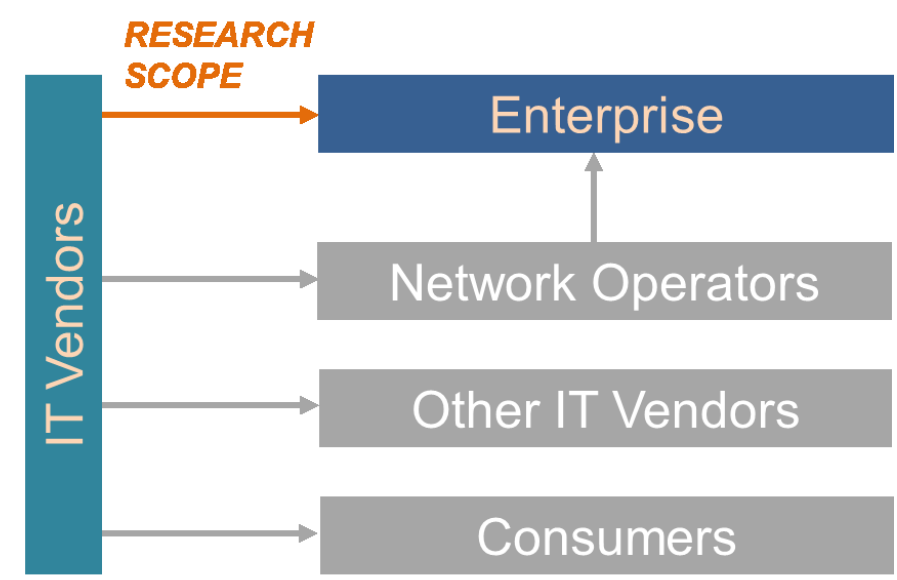

Source: Author's illustration

\section{Content categories}

Business and product descriptions were searched in view of the reference to ITbuyers' competitiveness or the competitive advantage that would result from the use of the IT products. In most cases, ITVs describe their competition, their rivals, and their position in the marketplace. These items are of interest to investors when reading an annual report. Thus, the content needed to be carefully checked in order to 
accurately distinguish the competitive context of enterprises from the competitive context of ITVs.

The procedure was as follows. First, the search string "compete" was used. Second, the sentences and paragraphs around the hits were checked for competitive context (competition among ITVs was ignored). Third, the entire business and product descriptions were studied again to find more connections to IT-buyer competition and to verify the previous search results. The typical and most numerous hits of the search string were "competition," "competitive advantage," and "competitiveness." Some hits were similar expressions such as "competitive agility" and "competitive differentiators." In addition, phrases that clearly indicate competitiveness but do not literally express it were considered, e.g., "give our clients a distinct advantage" and "to grow and win in the market." The latter procedure was more interpretive but still valid.

According to the Mayring's step model (2000) for deductive category application, the definitions of categories should be based on a theory. In terms of value, the customer-value disciplines of Treacy and Wiersema (1995) were chosen as the theoretical ground. As a result, the following categories were defined:

- Competitiveness

- Customer intimacy

- Operational excellence

- Product leadership

The analysis of the competitiveness category was separated from the customerintimacy, operational excellence, and product-leadership categories that constitute the customer-value disciplines. The categories of customer-value disciplines are mutually exclusive and collectively exhaustive, as stated by Chadwick, Bahar, and Albrecht (1984). Each item of coded content is allocated into exactly one analytical category without any intersections, and all categories must cover all codes. As suggested by Mayring (2000), the next stage was the formulation of coding rules for the categories. It began with choosing the units of analysis.

\section{Selection of units of analysis}

Units of analysis can be single words or entire articles, and they are coded into the content categories (Prasad, 2008). As units of analysis, I chose from the documents the sentences and paragraphs (context units) that contained keywords (recording units) as displayed in Table 1. This table represents a coding agenda consistent with the ideas of Mayring (2000). As proposed by Berelson (1952), context units are larger objects to be searched in order to describe the recording units more extensively.

Because complete sentences and paragraphs were regarded for coding, interpretations and subjective judgments were necessary to infer meanings in the data. Therefore, latent coding was applied, although the reliability is lower than in manifest coding, which identifies factual objects (Saunders, Lewis, and Thornhill, 2016). Manifest coding ignores context and would have been inappropriate for answering the research question. Many pertinent codes would have been overlooked, while several other hits on keywords would have been irrelevant.

Hsieh and Shannon (2005) showed three different qualitative ways to analyze content: directed, summative, and conventional. The summative analysis was used for the category "competitiveness." That is, keywords were specified during the document study to understand their contextual use through interpretation. In contrast, analysis of customer-value disciplines was carried by directed analysis. Categories and code units were predetermined by a theory. In that case, the keywords for recording units were taken from Treacy and Wiersema (1995). Both of 
the selected approaches from Hsieh and Shannon (2005) comply with the latentcoding methodology.

Table 1

Coding Agenda

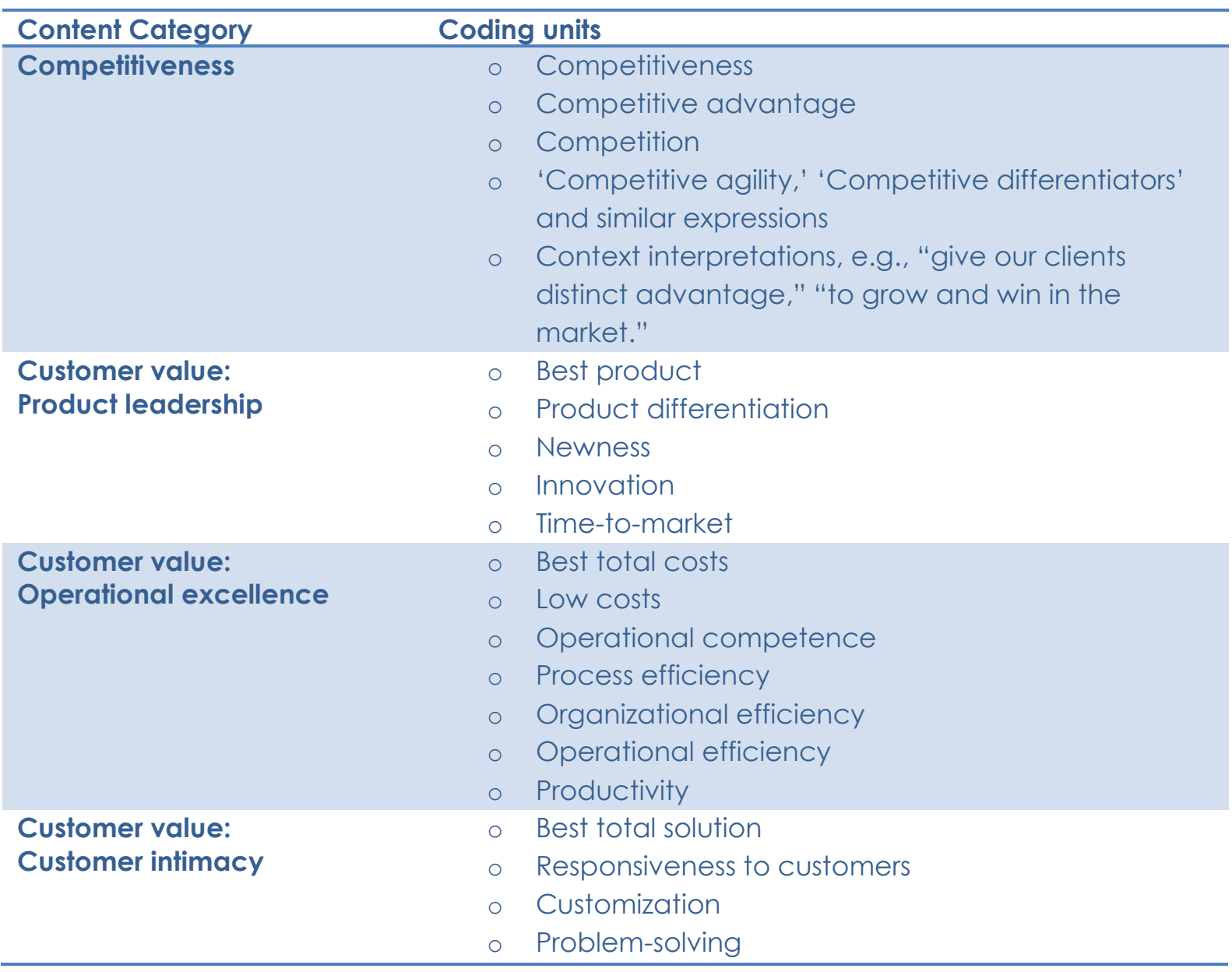

Source: Author's work

\section{Preparation of a coding agenda}

The content category "competitiveness," i.e., the definition of coding units and their allocation to content categories, was iteratively developed by studying annual reports and adding keywords as recordings units. Prior to beginning the complete content analysis of all samples, the coding agenda was piloted for all content categories. First, applicability was tested on three annual reports. Second, inconsistencies and inadequacies in the setup were corrected. Third, recording units were adjusted. Table 1 displays the final coding agenda for the examination of the full set of selected annual reports.

\section{Data collection and evaluation}

Prasad (2008) and Stemler (2001) recommended frequency as one method of enumeration. Other suggested methods, such as space or direction, were not applicable. Units of analysis were measured in terms of the number of times a context unit was found in the body of a product or business text in an annual report. Detailed data may be requested from the author. 


\section{Results}

\section{Descriptive findings}

In order to learn how ITVs present their buyers' competitiveness and customer value in product and business descriptions, 32 annual reports from world-leading IT suppliers were studied. Eighteen annual reports applied in the Form 10-K, as required by the SEC. Firms applying Form $10-K$ described their business in Part I, Item 1 on four pages as a minimum and on 15 pages as a maximum. The average number of pages used for business portrayals in Form 10-K was 10.3. Some firms (Cisco, Accenture) extended Form 10-K with forewords, business charts, figures, and summaries that were not evaluated. Other ITVs, not reporting according to SEC standards (e.g., Atos, Dassault Systèmes, CGI, SAP, and Wipro), made use of enlarged annual reports of more than 150 pages to further build their brand and enhance their attractiveness to investors. Those reports show a higher number of context units than reports with Form 10-K. Table 2 provides an overview of the number of coded context units found according to categories. Figure 3 presents the share of customer-value disciplines.

Table 2

Number of hits of context units in annual reports

\begin{tabular}{|c|c|c|c|c|c|}
\hline \multirow[b]{2}{*}{ IT Vendor } & \multirow[b]{2}{*}{ Form 10-k } & \multirow[b]{2}{*}{$\begin{array}{l}\text { Competit } \\
\text { iveness }\end{array}$} & \multicolumn{3}{|c|}{ Customer Value Discipline } \\
\hline & & & $\begin{array}{c}\text { Product } \\
\text { Leadership }\end{array}$ & $\begin{array}{l}\text { Operational } \\
\text { Excellence }\end{array}$ & $\begin{array}{l}\text { Customer } \\
\text { Intimacy }\end{array}$ \\
\hline Accenture & Yes & 2 & 2 & 4 & - \\
\hline Apple & Yes & - & - & - & - \\
\hline Atos & No & 10 & 5 & 5 & 3 \\
\hline Capgemini & No & 2 & 1 & 1 & - \\
\hline CGI & No & 6 & - & 3 & - \\
\hline Check Point Software & Yes & - & - & 2 & - \\
\hline Cisco Systems & Yes & 4 & 2 & 1 & - \\
\hline Compal & No & 1 & 1 & - & - \\
\hline CSC & Yes & 1 & - & 1 & - \\
\hline Dassault Systems & No & 3 & 3 & 3 & 4 \\
\hline EM C & Yes & 4 & 2 & 4 & - \\
\hline Fujitsu & No & 2 & 2 & 1 & - \\
\hline Google & Yes & - & - & - & - \\
\hline HCL Technologies & No & - & 2 & 6 & - \\
\hline Hewlett-Packard & Yes & - & - & 2 & 1 \\
\hline IBM & Yes & 1 & 2 & 5 & 1 \\
\hline Infosys & No & 1 & - & 2 & - \\
\hline Lenovo Group & No & - & 1 & - & - \\
\hline Microsoft & Yes & - & - & 4 & - \\
\hline Motorola Solutions & Yes & - & 2 & 2 & - \\
\hline NCR & Yes & - & - & 1 & - \\
\hline Net App & Yes & 1 & 1 & 5 & - \\
\hline Oracle & Yes & - & - & 7 & 1 \\
\hline Quanta & No & - & - & - & - \\
\hline San Disk & Yes & - & - & - & - \\
\hline SAP & No & 2 & 2 & 6 & 3 \\
\hline Seagate Technology & Yes & - & - & 1 & - \\
\hline Symantec & Yes & - & - & - & - \\
\hline Tata Consultancy S. & No & 1 & 2 & 1 & - \\
\hline VM Ware & Yes & - & 4 & 5 & - \\
\hline Wipro & No & 2 & 6 & 6 & 2 \\
\hline ZTE & No & - & 2 & - & - \\
\hline
\end{tabular}

Source: Author's work 
Half of the sampled documents contained context units for competitiveness (16 out of 32). Most of them (11) contained only one or two context units. At least one customer-value discipline was considered in 27 of the 32 annual reports. Twelve companies mentioned customer-value discipline without codes for competitiveness. All ITVs that mentioned competitiveness also referred to at least one customer-value discipline.

Five ITVs (Apple, Google, Quanta, SanDisk, and Symantec) did not mention either competitiveness or customer-value discipline. When ITVs referred to customer-value discipline, operational excellence was the most used (58\%), while customer intimacy (11\%) was the least considered (Figure 3). In $71 \%$ of the cases in which operational excellence was mentioned, another customer-value discipline was also found. High counts (8-11) of customer-value disciplines in comparison to the average count (4.22) were identified for eight companies ( $25 \%$ of the sample).

Figure 3

Percentage shares of customer-value disciplines

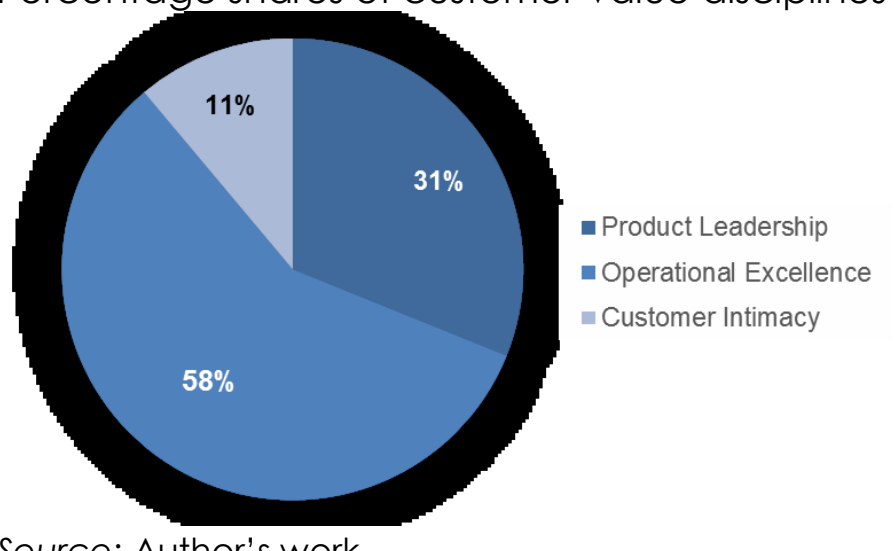

Source: Author's work

\section{Correlation of content categories}

Correlation coefficients of the sampled data were computed by the aid of R Studio software to determine the strength of associations between variables. Table 3 displays the results of multivariate statistical analysis (Cohen et al., 2003).

Table 3

Correlation coefficients $r$ of content categories based on the number of codes in samples

\begin{tabular}{lccc}
\hline & Competitiveness & $\begin{array}{c}\text { Product } \\
\text { Leadership }\end{array}$ & $\begin{array}{c}\text { Operational } \\
\text { Excellence }\end{array}$ \\
\hline Product Leadership & $0.4849^{* *}$ & & \\
Operational Excellence & 0.2804 & $0.4964^{* *}$ & \\
Customer Intimacy & $0.4676^{* *}$ & $0.5416^{* *}$ & $0.4733^{* *}$ \\
\hline
\end{tabular}

Note: ${ }^{* *}$ Correlation is significant at the 0.01 level (two-tailed)

Source: Author's work

The linear relationship between competitiveness and operational excellence is weak and uphill ( $r=0.2804$; not statistically significant). All other relationships are moderately positive and statistically significant ( $p<0.01)$.

To check internal consistency, Cronbach's alpha was calculated (Cronbach, 1951). The average inter-item correlation (the mean of $r$ in white fields in Table 3 ) is $r+t$ $=0.4574$. This value was corrected by the Spearman-Brown formula (1): 


$$
\frac{k \cdot r_{t t}}{1+(k-1) \cdot r_{t t}}=\frac{4 \cdot 0.4574}{1+3 \cdot 0.4574}=0.7713
$$

Cronbach's alpha values greater than 0.7 are acceptable (Nunnally, 1978). Spearman's rank order rho was also worked out. Results between 0.9551 and 0.9859 show monotonic relationships for all combinations.

Besides the data in the correlation matrix, a weak negative relationship between Form 10-K usage and the number of codes for competitiveness was found $(r=-$ 0.3308; the two-tailed significance level of 0.1 ).

In addition to the previous descriptive interpretation of the results, the consistencytested correlation matrix indicates moderate positive relationships of content categories. Linearity and homoscedasticity are assumed, i.e., the relationship line between the values is straight, not curved. The distance between the line and the values in a scatter diagram should look like a tube, not like a cone.

\section{Discussion}

\section{Operational excellence is the predominant customer-value type}

The investigation of annual reports from ITVs was conducted to gain a more profound understanding of the context of IT products and business strategy. The first research question raised was "What types of customer value do ITVs consider?" As reflected in the literature analysis, there is a consensus among scientists that the notion of value creation still needs more clarification (Gandelman, Cappelli, and Santoro, 2017; Lieberman, Balasubramanian, and Garcia-Castro, 2018; Singh and Paliwal, 2012). In his analysis of IT business values, Tallon (2007) applied Treacy and Wiersema's (1995) customer-value disciplines for the formulation and testing of hypotheses. The content analysis as presented here shows that those disciplines (operational excellence, product leadership, and customer intimacy) are suitable for categorizing IT values. Of the investigated documents, $84 \%$ included coding units of customer-value disciplines. Three out of four annual reports contained coding units for operational excellence; it was the most frequent customer value (58\% of coding-unit hits), followed by product leadership (31\%). The following conclusions may be drawn: The main reason for investments in IT products is to increase operational competence and process efficiency in order to lower costs, which provides monetary advantages to customers. Another important driver for IT products is differentiation by delivering innovative and beneficial functions to customers. The observations and conclusions perfectly fit the value definition of Porter (1985), which was cited previously in the literature review.

\section{Customer-value creation is the key to competitiveness}

In addition to the matter of customer-value types, another question looked at competitiveness in the context of customer values. According to Dranove and Marciano (2005), value creation is the key to competitiveness. Many renowned scholars have maintained that IT products deliver value and provide competitive advantage consequently (Clemons and Row, 1991; Drnevich and Croson, 2013; McAfee and Brynjolfsson, 2008; Peppard and Ward, 2004, 2005; Venkatraman, Henderson, and Oldach, 1993), but they have not provided empirical evidence of that claim. Accordingly, another objective was to search coding units for competitiveness in the annual reports of ITVs to answer the second research 
question: "Do ITVs consider the competitiveness of enterprises?" Content analysis showed that half of the sampled annual reports from ITVs mentioned the competitiveness of their enterprise buyers. If ITVs referred to enterprise competitiveness, they also mentioned one or more customer-value disciplines. In other words, ITVs that consider the competitiveness of IT buyers are also pointing out value creation to end customers. Taking the moderate positive relationships between competitiveness and customer-value types into account, it may be suggested that enterprise competitiveness is dependent on customer-value creation.

\section{Additional discoveries}

Further outcomes of this study are moderate positive correlations among customervalue disciplines. It is possible to hypothesize that ITVs support multiple customervalue types rather than focusing on a single customer value.

From the negative relationship between Form 10-K usage and the number of codes for competitiveness ( $r=-0.3308)$, it can be inferred that ITVs applying Form 10$\mathrm{K}$ tend to include fewer codes than vendors not obliged to report in 10-K format due to the annual report's limited extent.

Few companies that pointed to customer intimacy are strong competitors in the same market segment (Oracle vs. SAP in the software market for enterprise resource planning; Hewlett Packard vs. IBM for the supply of data-center infrastructure and server solutions).

The data also support an idea suggested by Han, Kuruzovich, and Ravichandran (2013), who argued that hardware products need little customization, whereas software customizations must match the business processes of customers. "Customization" is a coding unit of the content category of customer intimacy. Besides Atos, the most codes for customer intimacy were found at SAP and Dassault Systèmes; both are software vendors.

\section{Limitations}

In this investigation, there are potential sources of error that impact reliability. Although the data collection aimed at objectivity, researcher bias influenced the search for codes. Latent content analysis calls for minor interpretations of codes, which therefore may reflect the subjective views of the researcher. Also, researcher errors exist due to unconscious altered interpretations of codes. Codes could also have been misunderstood or overlooked.

Although the sample size has previously been justified as being appropriate to the purpose, the sample size is viewed as a limitation, as the samples do not represent the whole population of ITVs.

Another restriction is that content analysis is not suited to explaining causality (Saunders, Lewis, and Thornhill, 2016). Correlations among content categories do not imply cause-and-effect relationships.

As a primary research method, content analysis is constrained for the synthesis of meanings. The counting of the hits of codes does not necessarily mirror the importance of the phenomenon (Dixon-Woods et al., 2005). For example, from the high number of counts for operation excellence (78 hits) as compared to the low frequency for customer intimacy ( 15 hits), it may not be concluded that operational excellence is significantly more important than customer intimacy.

Another weakness of this study is the use of secondary data from the documents since the annual reports are not produced for research; they lack the details that would allow in-depth answers to the research question (Bowen, 2009). 


\section{Future research}

To enhance the generalizability of the findings, sample size can be increased, e.g., by including medium-sized ITVs in the scope of research or by inspecting the annual reports of the same vendors from other years. The coding agenda could also be applied to other types of vendor documents, such as brochures, manuals, and the Internet sites of ITVs (web-content analysis). In addition, inter-coder reliability could be proven to increase stability and reproducibility (Stemler, 2001). Another coder could take the same samples and determine whether the units were placed in the same categories (Stempel, 1989).

The results of this research offer a foundation for additional studies. In subsequent deductive research, the presented propositions might be hypothesized and proved or disproved by conducting empirical tests. Additionally, the perspective could be changed from the supplier to the buyer side. Semi-structured interviews with strategists and IT executives from enterprises would extend knowledge of the phenomenon. Investigations of the causalities of the described relations offer great opportunities for more contributions to theory and practice.

Further research might investigate relationships between type of customer value and type of ITV. For instance, system integrators, consultancy firms, and outsourcers that work in close cooperation with enterprises might focus more on customer intimacy than on any other customer-value type. Finally, new research questions can be framed on the relations between types of IT products and types of customer values.

\section{Conclusion}

The goal of this article was to broaden the understanding of the relation between IT products and business strategy with respect to competitiveness and customer value. Codes for competitiveness and customer-value disciplines were searched for in the product and business descriptions of annual reports from world-leading ITVs. These ITVs take into account the competitiveness of their buyers and the customer value from their products. IT products increase the competitiveness of enterprises by providing value to end customers.

This exploratory study detected patterns and moderate correlations between competitiveness and customer-value disciplines. The customer-value disciplines as described by Treacy and Wiersema (1995) are applicable for classifying customer values from IT products. Operational excellence is the most prevalent value discipline. It refers to the process efficiency and cost-effectiveness, resulting in monetary benefits for customers. Another substantial customer-value type is product leadership that is about innovation and functional benefits. I recommend that IT managers plan their investments in IT products by their contributions to customer value.

Future research may evaluate data from newer annual reports or from other types of documents. Yet, the main limitations of this work are the use of secondary data and the lack of causality. In order to counter this, the propositions can be hypothesized and quantitatively be tested by collecting primary data from surveys. Causality regarding customer value and IT products can be investigated by interviewing executives from ITVs and IT product buyers. This study opens various paths for further examinations. I hope to inspire more research on the phenomenon. 


\section{References}

1. Barney, J. (1991), "Firm Resources and Sustained Competitive Advantage", Journal of Management, Vol. 17, No. 1, pp. 99-120.

2. Bengtsson, M. (2016), "How to plan and perform a qualitative study using content analysis", NursingPlus Open, Vol. 2, pp. 8-14.

3. Berelson, B. (1952), Content analysis in communication research, New York, Free Press.

4. Berman, S., Marshall, A. (2014), "Reinventing the rules of engagement: three strategies for winning the information technology race", Strategy \& Leadership, Vol. 42, No. 4, pp. 2232.

5. Bharadwaj, A. S. (2000), "A Resource-Based Perspective on Information Technology Capability and Firm Performance: An Empirical Investigation", MIS Quarterly, Vol. 24, No. 1, pp. 169-196.

6. Bowen, G. A. (2009), "Document Analysis as a Qualitative Research Method", Qualitative Research Journal, Vol. 9, No. 2, pp. 27-40.

7. Brislin, R. W. (1979), "Translation and Content Analysis of Oral and Written", in Triandis, H. C., Berry, J. W. (Eds.), Handbook of Cross-Cultural Psychology Volume 2: Methodology, Boston / MA, Allyn \& Bacon, pp. 389-438.

8. Chadwick, B. A., Bahar, H. M., Albrecht, S. L. (1984), "Content analysis”, in Chadwick, B. A., Bahr, H. M., Albrecht, S. L. (Eds.), Social Science Research Methods, New Jersey, Prentice-Hall, pp. 239-257.

9. Chicksand, D., Rehme, J. (2018), "Total value in business relationships: exploring the link between power and value appropriation", Journal of Business \& Industrial Marketing, Vol. 33, No. 2, pp. 174-182.

10. Christensen, H. K. (2010), "Defining customer value as the driver of competitive advantage", Strategy \& Leadership, Vol. 38, No. 5, pp. 20-25.

11. Clemons, E. K., Row, M. C. (1991), "Sustaining IT Advantage: The Role of Structural Differences", MIS Quarterly, Vol. 15, No. 3, pp. 275-292.

12. Cohen, J., Cohen, P., West, S. G., Aiken, L. S. (2003), Applied multiple regression/correlation analysis for the behavioral sciences, 3rd edition, Hillsdale, Erlbaum.

13. Creswell, J. W. (2013), Research Design: Qualitative, Quantitative, and Mixed Methods Approaches, 4th edition, Thousand Oaks/CA, Sage.

14. Cronbach, L. J. (1951), "Coefficient alpha and the internal structure of tests", Psychometrika, Vol. 16, No. 3, pp. 297-334.

15. Daulatkar, S., Sangle, P. S. (2016), "Proposed re-conceptualization of IT business value benefits", Business Process Management Journal, Vol. 22, No. 3, pp. 522-545.

16. Dixon-Woods, M., Agarwal, S., Jones, D., Young, B., Sutton, A. (2005), "Synthesising qualitative and quantitative evidence: a review of possible methods", Journal of Health Services Research \& Policy, Vol. 10, No. 1, pp. 45-53.

17. Downe-Wamboldt, B. (1992), "Content analysis: Method, applications, and issues", Health care for women international, Vol. 13, No. 3, pp. 313-321.

18. Dranove, D., Marciano, S. (2005), "Kellogg on Strategy - Concepts, Tools, and Frameworks for Practitioners", Hoboken / NJ, John Wiley \& Sons.

19. Drnevich, P. L., Croson, D. C. (2013), "Information Technology and Business-LevelStrategy", MIS Quarterly, Vol. 37, No. 2, pp. 483-509.

20. Duc, N. N., Siengthai, S., Page, S. (2013), "A conceptual model of HRIS-Trust: an understanding of suppliers'/customers' relationship", Foresight, Vol. 15, No. 2, pp. 106-116.

21. El-Mekawy, M., Rusu, L., Perjons, E. (2015), "An evaluation framework for comparing business-IT alignment models: A tool for supporting collaborative learning in organizations", Computers in Human Behavior, Vol. 51, pp. 1229-1241.

22. Elo, S., Kyngäs, H. (2008), "The qualitative content analysis process", Journal of Advanced Nursing, Vol. 62, No.1, pp. 107-115.

23. Feeny, D. F., Willcocks, L. P. (1998), "Core IS Capabilities for Exploiting Information Technology", Sloan Management Review, Vol. 39, No. 3, pp. 9-22.

24. Gandelman, R. T., Cappelli, C., Santoro, F. M. (2017), "Toward a Prescriptive Catalog for IT Value", in Proceedings of the 10th IADIS International Conference on Information Systems, Budapest, Hungary, pp. 225-228. 
25. Gellweiler, C. (2017), "Bridging IT requirements to competitive advantage: The concept of IT value planning", Procedia Computer Science, Vol. 121, pp. 145-151.

26. Goh, S. C., Ryan P. J. (2008), "The organizational performance of learning companies: A longitudinal and competitor analysis using market and accounting financial data", The Learning Organization, Vol. 15, No. 3, pp. 225-239.

27. Han, S., Kuruzovich, J., Ravichandran, T. (2013), "Service Expansion of Product Firms in the Information Technology Industry: An Empirical Study", Journal of Management Information Systems, Vol. 29, No. 4, pp. 127-158.

28. Hsieh, H., Shannon, S. E. (2005), "Three approaches to qualitative content analysis", Qualitative health research, Vol. 15, No. 9, pp. 1277-1288.

29. IEEE (2017), "Guide to the Enterprise Body of Knowledge (EITBOK)", available at: http://eitbokwiki.org/Main Page (01 March 2018)

30. IIBA (2015), A Guide to Business Analysis Body of Knowledge (BABOK V3.0), Toronto, International Institute for Business Analysis.

31. ISACA (2010), The Business Case Guide: Using Val ITTM 2.0., Rolling Meadows, IL, Information Systems Audit and Control Association.

32. ISACA (2012), COBIT V5 - A Business Framework for the Governance and Management of Enterprise IT, Rolling Meadows, IL, Information Systems Audit and Control Association.

33. Lederer, A. L., Salmela, H. (1996), "Toward a theory of strategic information systems planning", Journal of Strategic Information Systems, Vol. 5, No. 3, pp. 237-253.

34. Lieberman, M.B., Balasubramanian, N., Garcia-Castro, R. (2018), "Toward a dynamic notion of value creation and appropriation in firms: The concept and measurement of economic gain", Strategic Management Journal, Vol. 39, No. 6, pp. 1546-1572.

35. Luftman, J. (2003), "Assessing IT / Business Alignment", Information Systems Management, Vol. 20, No. 4, pp. 9-15.

36. Marrone, M., Kolbe, L. M. (2011), "Uncovering ITIL claims. IT executives' perception on benefits and Business-IT alignment", Information Systems and e-Business Management, Vol. 9, No. 3, pp. 363-380.

37. Martins, P. V., Zacarias, M. (2017), "Applying the Business Process and Practice Alignment Meta-model: Daily Practices and Process Modelling", Business Systems Research Journal, Vol. 8, No.1, pp. 1-16.

38. Mayring, P. (2000), "Qualitative Content Analysis", Forum: Qualitative Social Research, Vol. 1, No. 2, available at: http://www.qualitative-research.net/index.php/fas/article/view/1089/2385 (24 February 2018).

39. McAfee, A., Brynjolfsson, E. (2008), "Investing in the IT that makes a competitive difference", Harvard Business Review, Vol. 86, No. 7-8, pp. 98-107.

40. Myers, M. D. (2013), Qualitative Research in Business and Management, 2nd edition, Thousand Oaks/CA, Sage Publications.

41. Nunnally, J. C. (1978), Psychometric theory, 2nd edition, New York, McGraw-Hill.

42. Office of Government Commerce (2002), Prince2, 3rd edition, London, The Stationary Office.

43. Palinkas, L. A., Horwitz, S. M., Green, C. A., Wisdom, J. P., Duan, N., Hoagwood, K. (2015), "Purposeful sampling for qualitative data collection and analysis in mixed method implementation research", Administration and Policy in Mental Health and Mental Health Services Research, Vol. 42, No. 5, pp. 533-544.

44. Peppard, J., Ward, J. (2004), "Beyond strategic information systems: towards an IS capability", Journal of Strategic Information Systems, Vol. 13, No. 2, pp. 167-194.

45. Peppard, J., Ward, J. (2005), "Unlocking Sustained Business Value from IT Investments", California Management Review, Vol. 48, No. 1, pp. 52-70.

46. Peppard, J., Ward, J. (2016), The Strategic Management of Information Systems - Building a Digital Strategy. 4th edition. Hoboken/NJ, John Wiley \& Sons.

47. Pope, C., Ziebland, S., Mays, N. (2000), "Qualitative research in health care Analysing qualitative data", British Medical Journal, Vol. 320, pp. 114-116.

48. Porter, M. E. (1980), Competitive Strategy, New York, Free Press.

49. Porter, M. E. (1985), Competitive Advantage, New York, Free Press. 
50. Prasad, B. D. (2008), "Content Analysis - A method in Social Science Research", in Lal Das, D. K., Bhaskaran, V. (Eds.), Research methods for Social Work, New Delhi, Rawat, pp. 173193.

51. Robertson, F. A., Samy, M. (2015), "Factors affecting the diffusion of integrated reporting a UK FTSE 100 perspective", Sustainability Accounting, Management and Policy Journal, Vol. 6, No. 2, pp. 190-223.

52. Sandelowski, M. (1995), "Sample Size in Qualitative Research", Research in Nursing \& Health, Vol. 18, No. 2, pp. 179-183.

53. Sandelowski, M. (2000), "Whatever Happened to Qualitative Description?", Research in Nursing \& Health, Vol. 23, No. 4, pp. 334-340.

54. Saunders, M., Lewis, P., Thornhill, A. (2016), Research methods for business students, 7th edition, Harlow, Pearson.

55. Singh, R., Paliwal, P. (2012), "Customers' value appraisals-suppliers' value propositions interaction process in developing new services: A case study from the natural gas industry", International Journal of Energy Sector Management, Vol. 6 No. 2, pp. 255-272.

56. Stemler, S. (2001), "An Overview of Content Analysis", Practical Assessment, Research \& Evaluation", Vol. 7, No. 17, available at: http://PAREonline.net/getvn.asp? $v=7 \& n=17$ (10 March 2018),

57. Stempel, G. H. (1989), "Content analysis", in Stempel, G. H., Westley, B. H. (Eds.), Research methods in mass communications, Englewood Cliffs / NJ, Prentice-Hall.

58. Tallon, P. P. (2007), "Does IT pay to focus? An analysis of IT business value under single and multi-focused business strategies", Journal of Strategic Information Systems, Vol. 16, No. 3, pp. 278-300.

59. The Open Group (2011), TOGAF Version 9.1, Zaltbommel, Van Haren Publishing.

60. Treacy, M., Wiersema, F. (1995), The discipline of market leaders: Choose your customers, narrow your focus, dominate your market, Reading/MA, Addison-Wesley.

61. Van de Ven, A. H. (2007), Engaged Scholarship: A Guide for Organizational and Social Research, New York, Oxford University Press.

62. Venkatraman, N., Henderson, J. C., Oldach, S. (1993), "Continuous Strategic Alignment: Exploiting Information Technology Capabilities for Competitive Success", European Management Journal, Vol. 11, No. 2, pp. 139-149.

63. Vishnevskiy, K., Karasev, O., Meissner, D. (2016), "Integrated roadmaps for strategic management and planning", Technological Forecasting \& Social Change, Vol. 110, pp. 153-166.

64. Wade, M., Hulland, J. (2004), "Review: The Resource-Based View and Information Systems Research: Review, Extension, and Suggestions for Future Research", MIS Quarterly, Vol. 28 No. 1, pp. 107-142.

65. Ward, J. M. (2012), "Information systems strategy: Quo vadis?", Journal of Strategic Information Systems, Vol. 21, No. 2, pp. 165-171.

\section{About the author}

Christof Gellweiler is IT project management consultant with more than 25 years of professional experience in the financial services industry and the IT infrastructure business in Germany. He holds a diploma in telecommunication engineering from University of Applied Sciences TH Bingen and earned an Executive-MBA from Kellogg-WHU. As a doctoral student at BI Norwegian Business School and ISM Vilnius, Christof's research focused on competitive strategy and IT value planning. He is certified by PMI and Cisco Systems and teaches international project management at various universities in Germany and Lithuania. The author can be contacted at christof.gellweiler@whu.edu. 